\title{
Antioxidant, Antinociceptive, and Anti-inflammatory Properties of the Ethanolic Extract of Combretum duarteanum in Rodents
}

\author{
Marcos G.S. Gouveia, Maria A. Xavier, André S. Barreto, Daniel P. Gelain, João P.A. Santos, \\ Adriano A.S. Araújo, Francilene A. Silva, Jullyana S. Quintans, ${ }^{1}$ Maria F. Agra, ${ }^{2}$ \\ Analúcia G.S. Cabral, ${ }^{2}$ Josean F. Tavares, ${ }^{2}$ Marcelo S. Silva, ${ }^{2}$ and Lucindo J. Quintans-Júnior ${ }^{1}$ \\ ${ }^{1}$ Department of Physiology, Universidade Federal de Sergipe, São Cristóvão, Sergipe, Brazil. \\ ${ }^{2}$ Laboratory of Pharmaceutical Technology, Universidade Federal da Paraíba, João Pessoa, Paraíba, Brazil.
}

\begin{abstract}
The antioxidant, antinociceptive, and anti-inflammatory activities of the ethanolic extract from leaves of Combretum duarteanum (EEC) were assessed in rodents through in vitro tests. The antioxidant activity was investigated by using thiobarbituric acid reactive species (TBARS), hydroxyl radical-scavenging, and scavenging activity of nitric oxide assays. The antinociceptive activity was investigated by using acetic acid-induced writhing, formalin, and hot-plate tests in mice. The anti-inflammatory activity was assessed in rats by using the carrageenan-induced hind-paw edema test and arachidonic acid-induced paw edema test. EEC possesses a strong antioxidant potential according to the TBARS, nitric oxide, and hydroxyl radical-scavenging assays; it also presented scavenger activity in all in vitro tests. After intraperitoneal injection, EEC $(100,200$, and $400 \mathrm{mg} / \mathrm{kg})$ significantly reduced the number of writhes $(38.1 \%, 90.6 \%$, and $97.8 \%$, respectively) in a writhing test and the number of paw licks during phase 1 (30.5\% and 69.5\%, higher doses) and phase $2(38.1 \%$, $90.6 \%$, and $97.8 \%$, all doses) of a formalin test when compared with the control group. Naloxone (1.5 mg/kg, intraperitoneally) antagonized the antinociceptive action of EEC $(400 \mathrm{mg} / \mathrm{kg})$, and this finding suggests participation of the opioid system. Administration of 200 and $400 \mathrm{mg} / \mathrm{kg}$ (intraperitoneally) of EEC exhibited an anti-inflammatory activity in the carrageenin test, which was based on interference with prostaglandin synthesis. This finding was confirmed by the arachidonic acid test. Together, these results indicate that properties of EEC might be further explored in the search for newer tools to treat painful inflammatory conditions, including those related to pro-oxidant states.
\end{abstract}

\section{KEY WORDS: • anti-inflammatory • antioxidant $\bullet$ Combretum duarteanum • medicinal plants • pain}

\section{INTRODUCTION}

$\mathbf{M}$ EDICINAL PLANTS, THOSE CONSIDERED to possess therapeutic properties, have been used since the beginning of human civilization for treating disease. Their use for the promotion of human health has significantly increased in recent years because of several factors, including the safety, effectiveness, and improved quality control of the phytomedicines available on the market today. ${ }^{1-3}$ Although in recent years notable progress has been made concerning the development of natural therapies, there is an urgent need to discover effective and potent analgesic and anti-inflammatory agents. ${ }^{4-6}$

The plants of the family Combretaceae comprise 20 genera with approximately 600 species. The largest genera are Combretum, with about 370 species, and Terminalia, with about 200 species. ${ }^{7,8}$ Some species of Combretum have

Manuscript received 16 August 2010. Revision accepted 7 March 2011.

Address correspondence to: Lucindo J. Ouintans-Júnior Departamento de Fisiologia, Universidade Federal de Sergipe-UFS, Av. Marechal Rondom, s/n, São Cristúvão, Sergipe, Brazil, E-mail: lucindo_jr@yahoo.com.br; lucindo@pq.cnpq.br a broad spectrum of biological activities, including antibacterial, antiprotozoal, anticancer, cytotoxic, analgesic, and anti-inflammatory. ${ }^{7,9-12}$

C. duarteanum Cambess is a plant from the north and northeast of Brazil, known by the popular names "vaqueta" and "caatinga-branca." 8,13 Its leaves are used for teas, drinks, and food supplements for the indigenous populations of northeast Brazil. ${ }^{8,14}$ Infusions prepared with the aerial parts (stems and leaves) of $C$. duarteanum are used in folk medicine for the treatment of pain and as sedative. ${ }^{8,14}$ However, we found no relevant literature substantiating the botanical, chemical, and pharmacologic studies of this species.

Free radicals and related reactive species are involved in several pathologic and physiologic processes, including cancer, cell death, inflammation, and pain. ${ }^{15}$ Many natural products exert significant redox activities, which are related to their therapeutic properties or even a possible toxic effect. $^{16}$ The evaluation of the redox properties of such compounds is crucial for understanding the potential mechanisms of their biological actions and determining possible toxic or harmful side effects. Considering the lack of experimental evidence and scientific investigations on the 
possible therapeutic or redox properties of $C$. duarteanum, we sought to evaluate the redox properties and possible antinociceptive and anti-inflammatory effects of the ethanolic extract obtained from the leaves of $C$. duarteanum (EEC) in rodents.

\section{MATERIAL AND METHODS}

\section{Plant material}

Leaves of $C$. duarteanum were collected in the region around Serra Branca, Paraiba, Brazil, in March 2007. The plant was identified by Maria de Fátima Agra, $\mathrm{PhD}$, from the Federal University of Paraiba, and a voucher specimen was deposited at the Lauro Pires Xavier Herbarium (voucher number 6767).

\section{Preparation of EEC}

Leaves of C. duarteanum were dried in an oven at $40^{\circ} \mathrm{C}$ and subsequently pulverized. The plant material was cold macerated with ethanol $95 \%$ for 72 hours, and the extract was concentrated by using a rotary evaporator. A dry solid $(40 \mathrm{~g})$ was obtained, corresponding to a yield of $10 \%$.

\section{Chemicals}

Sodium nitroprusside, $\mathrm{FeSO}_{4}$, Griess modified reagent, 2-deoxyribose, 2-thio-barbituric acid, 2,2'-azobis[2-methylpropionamidine]dihydrochloride, trichloroacetic acid, Trolox ${ }^{\circledR}$ (6-hydroxy-2,5,7,8-tetramethylchroman-2-carboxilic acid), acetic acid, norhydroguaiaretic acid, and polyoxyethylenesorbitan monolate (Tween 80) were purchased from Sigma Co. Morphine naloxone, and aspirin (acetylsalicylic acid) were purchased from União Química. All drugs and the EEC were administered intraperitoneally in volumes of $0.1 \mathrm{~mL} / 10 \mathrm{~g}$ (mice) and $0.1 \mathrm{~mL} / 100 \mathrm{~g}$ (rats).

\section{Thiobarbituric acid reactive species assay}

Thiobarbituric acid reactive species (TBARS) assay was used to quantify lipid peroxidation, ${ }^{17}$ and an adapted TBARS method was used to measure the antioxidant capacity of EEC by using egg yolk homogenate as a lipid-rich substrate. ${ }^{16}$ Briefly, egg yolk was homogenized $(1 \% \mathrm{w} / \mathrm{v})$ in $20 \mathrm{mM}$ phosphate buffer ( $\mathrm{pH}, 7.4)$, and $1 \mathrm{~mL}$ of homogenate was sonicated and then homogenized with $0.1 \mathrm{~mL}$ of EEC at different concentrations. Lipid peroxidation was induced by addition of $0.1 \mathrm{~mL}$ of AAPH solution $(0.12 \mathrm{M})$. Control was only EEC vehicle (ethanol $0.1 \%$ ). Reactions were carried out for 30 minutes at $37^{\circ} \mathrm{C}$. After cooling, samples $(0.5 \mathrm{~mL})$ were centrifuged with $0.5 \mathrm{~mL}$ of trichloroacetic acid (15\%) at $1200 \mathrm{~g}$ for 10 minutes. An aliquot of $0.5 \mathrm{~mL}$ from supernatant was mixed with $0.5 \mathrm{~mL}$ TBA $(0.67 \%)$ and heated at $95^{\circ} \mathrm{C}$ for 30 minutes. After cooling, sample absorbance was measured by using a spectrophotometer at $532 \mathrm{~nm}$. The results were expressed as percentage of TBARS formed by AAPH alone (induced control).

\section{Hydroxyl radical-scavenging activity}

The formation of hydroxyl radical from Fenton reaction was quantified by using 2-deoxyribose oxidative degradation. ${ }^{18}$ The principle of the assay is the quantification of the 2-deoxyribose degradation product, malondialdehyde, by its condensation with TBA. Briefly, typical reactions were started by the addition of $\mathrm{Fe}^{2+}\left(\mathrm{FeSO}_{4} 6 \mathrm{mM}\right.$ final concentration) to solutions containing $5 \mathrm{mM}$ 2-deoxyribose, $100 \mathrm{mM}$ $\mathrm{H}_{2} \mathrm{O}_{2}$, and $20 \mathrm{mM}$ phosphate buffer ( $\mathrm{pH}, 7.2$ ). To measure EEC antioxidant activity against hydroxyl radical, different concentrations of EEC were added to the system before $\mathrm{Fe}^{2+}$ addition. Reactions were carried out for 15 minutes at room temperature and were stopped by the addition of $4 \%$ phosphoric acid (v/v) followed by $1 \%$ TBA (w/v, in $50 \mathrm{mM}$ $\mathrm{NaOH}$ ). Solutions were boiled for 15 minutes at $95^{\circ} \mathrm{C}$ and then cooled to room temperature. The absorbance was measured at $532 \mathrm{~nm}$, and results were expressed as malondialdehyde equivalents formed by $\mathrm{Fe}^{2+}$ and $\mathrm{H}_{2} \mathrm{O}_{2}$.

\section{Scavenging activity of nitric oxide}

Nitric oxide (NO) was generated from spontaneous decomposition of sodium nitroprusside in $20 \mathrm{mM}$ phosphate buffer ( $\mathrm{pH}, 7.4)$. Once generated, NO interacts with oxygen to produce nitrite ions, which were measured by the Griess reaction. ${ }^{19}$ The reaction mixture $(1 \mathrm{~mL})$ containing $10 \mathrm{mM}$ sodium nitroprusside in phosphate buffer and EEC at different concentrations were incubated at $37^{\circ} \mathrm{C}$ for 1 hours. A $0.5-\mathrm{mL}$ aliquot was taken and homogenized with $0.5 \mathrm{~mL}$ Griess reagent. The absorbance of chromophore was measured at $540 \mathrm{~nm}$. Percentage inhibition of nitric oxide generated was measured by comparing the absorbance values of negative controls (only $10 \mathrm{mM}$ sodium nitroprusside and vehicle) with assay preparations. Results were expressed as percentage of nitrite formed by sodium nitroprusside alone.

\section{Animals}

Male Swiss mice (weight, 27-32 g) and male Wistar rats (weight, 150-205 g), 2-3 months of age, were used throughout this study. The animals were randomly housed in appropriate cages at a mean temperature \pm standard deviation of $22^{\circ} \mathrm{C} \pm 1{ }^{\circ} \mathrm{C}$ on a 12 -hour/12-hour light/dark cycle (lights on 06:00-18:00) with free access to food (Purina) and water. Each group had 10 animals each. In the carrageenaninduced hind-paw edema test, each group consisted of 10 rats each. Experimental protocols and procedures were approved by the Federal University of Sergipe Animal Care and Use Committee (CEPA/UFS number 13/09).

\section{Acetic acid-induced writhing}

This test was done by using the method described by Koster $\mathrm{et} \mathrm{al.}{ }^{20}$ and Broadbear $\mathrm{et} \mathrm{al.} .^{21}$ Initially the mice were divided into 5 groups $(n=10)$. Subsequently, EEC (100, 200 , and $400 \mathrm{mg} / \mathrm{kg}$ ), vehicle (saline/Tween-80 0.2\%; control group), and morphine $(5 \mathrm{mg} / \mathrm{kg})$ were administered intraperitoneally 60 minutes before an injection of $0.85 \%$ acetic acid $(0.25 \mathrm{~mL} / \mathrm{animal})$. Each animal was isolated in 
an individual observation chamber, and 15 minutes after acetic acid injection the cumulative number of writhing responses was recorded for 15 minutes.

\section{Formalin test}

The formalin test was carried out as described by Hunskaar and Hole. ${ }^{22}$ The animals were divided into 6 groups $(n=10)$ and treated intraperitoneally with vehicle (control), EEC $(100,200$, and $400 \mathrm{mg} / \mathrm{kg})$, morphine $(5 \mathrm{mg} / \mathrm{kg})$, and aspirin ( $200 \mathrm{mg} / \mathrm{kg}$ ). After 60 minutes, $20 \mu \mathrm{L}$ of a $2.5 \%$ formalin solution $(0.92 \%$ formaldehyde) in a phosphate buffer $(\mathrm{pH}$, 7.2) was injected into the dorsal surface of the left hind paw using a microsyringe with a 26-gauge needle. The duration of paw licking was measured at 0-5 minutes (first phase) and 15-30 minutes (second phase) after formalin administration.

\section{Possible antagonism of the EEC antinociceptive effect by pretreatment with naloxone}

Mice were intraperitoneally pretreated $(n=10)$ with $1.5 \mathrm{mg} / \mathrm{kg}$ of naloxone, a nonselective opioid antagonist, 15 minutes before the intraperitoneal administration of vehicle (control), EEC $(400 \mathrm{mg} / \mathrm{kg})$, or morphine $(5 \mathrm{mg} / \mathrm{kg})$. Subsequently, the acetic acid-induced writhing test was performed as described above.

\section{Hot-plate test}

The hot-plate test was carried out as described by Eddy and Leimbach. ${ }^{23}$ In this test, reaction of mice to painful stimulus was measured. Mice were placed individually on a metal plate that was heated to $52^{\circ} \mathrm{C} \pm 0.5^{\circ} \mathrm{C}$ and covered with a glass cylinder $(25 \mathrm{~cm}$ high, $15 \mathrm{~cm}$ in diameter). The time elapsing to the first pain response (licking of the forepaws or jumping) was determined by a stopwatch and then recorded. The experiments were conducted 60 minutes after the intraperitoneal administration of the EEC (100, 200 , and $400 \mathrm{mg} / \mathrm{kg}$ ). The effect of pretreatment with naloxone $(1.5 \mathrm{mg} / \mathrm{kg}$, intraperitoneally) on the antinociception produced by EEC $(400 \mathrm{mg} / \mathrm{kg})$ and morphine $(5 \mathrm{mg} / \mathrm{kg}$, intraperitoneally) was determined.

\section{Rota-rod test}

Initially, the mice able to remain on the Rota-rod apparatus (AVS) longer than 180 seconds ( $9 \mathrm{rpm})$ were selected 24 hours before the test. ${ }^{24}$ Then, the selected animals were divided into 5 groups $(n=10)$ and treated intraperitoneally with vehicle (control), EEC (100, 200, and $400 \mathrm{mg} / \mathrm{kg}$ ), and diazepam $(3 \mathrm{mg} / \mathrm{kg})$. Thirty minutes later, each animal was tested on the Rota-rod and the time (in seconds) they remained on the bar for up to 180 seconds was recorded after 60 minutes.

\section{Carrageenan-induced hind-paw edema in rats}

Acute hind-paw edema was produced by injecting $0.1 \mathrm{~mL}$ of carrageenan (prepared as $1 \%$ suspension in distillate water) locally into the plantar aponeurosis of the right hind paw of rats. ${ }^{25}$ EEC $(100,200$, and $400 \mathrm{mg} / \mathrm{kg}$, intraperito- neally) was administered to different groups $(n=8)$; the other groups served as negative and positive controls and received vehicle (control) and the standard drug, aspirin $(200 \mathrm{mg} / \mathrm{kg}$, intraperitoneally), respectively. EEC and aspirin were administered 1 hour before the injection of carrageenan. The rat paw volume up to the ankle joint was measured by using a plethysmometer (LE 7500, PanLab) at 0 (just before) and 3 hours after the injection of carrageenan. Increase in the paw edema volume was considered as the difference between 0 and 3 hours.

\section{Arachidonic acid-induced rat paw edema}

Rat paw edema was induced in animal groups $(n=8)$ by subplantar injection into the right hind paw of $0.1 \mathrm{~mL} 0.5 \%$ arachidonic acid dissolved in carbonate buffer $(\mathrm{pH}, 8.5)$. Norhydroguaiaretic acid (NDGA, $100 \mathrm{mg} / \mathrm{kg}$ ) as reference and EEC (200 and $400 \mathrm{mg} / \mathrm{kg}$ ) were administered intraperitoneally 60 minutes before arachidonic acid injection. Edema volume was measured by plethysmography immediately after arachidonic acid injection and at 30-minute intervals thereafter for 2 hours. ${ }^{26}$

\section{Statistical analysis}

The obtained data were evaluated by 1-way analysis of variance followed by the Dunnett or Fisher test. All statistical analyses were done using GraphPad Prism 5.0 (GraphPad Prism Software Inc., San Diego, CA, USA). In all cases, differences were considered significant if the $P$ value was less than .05 .

The percentage inhibition by an antinociceptive agent was determined for the acetic acid-induced writhing and formalin tests by using the following formula: Inhibition $\%=100 \times($ control-experiment $) /$ control. ${ }^{27}$ Percentage inhibition of edema volume between treated and control groups was calculated by using the following formula: Inhibition $\%=100 \times\left(V_{c}-V_{t}\right) / V_{c}$, where $V_{c}$ and $V_{t}$ represent mean increases in paw volume in the control and the treated groups, respectively.

\section{RESULTS AND DISCUSSION}

Membrane lipids are the most susceptible target of freeradical attack and propagation in biological systems. ${ }^{28} \mathrm{Ad}-$ ditionally, free radicals and related reactive species are strongly involved in several pathologic and physiologic processes, including cancer, cell death, inflammation, and pain. ${ }^{15,19}$ Thus, we assessed the antioxidant potential of EEC by testing its ability to prevent oxidative damage to lipids induced by a free-radical source in vitro (AAPH). Quantification by TBARS demonstrated that EEC exerts a significant antioxidant effect against peroxyl radicals generated by AAPH, protecting lipids from oxidation in a dosedependent fashion (Fig. 1). Trolox $(300 \mu \mathrm{M})$, a synthetic analogue of vitamin $\mathrm{E}$ that protects membranes from oxidative damage in vivo, was used as a general antioxidant standard for comparison. Therefore, it is possible that EEC interacts more strongly with specific types of lipids. In a 


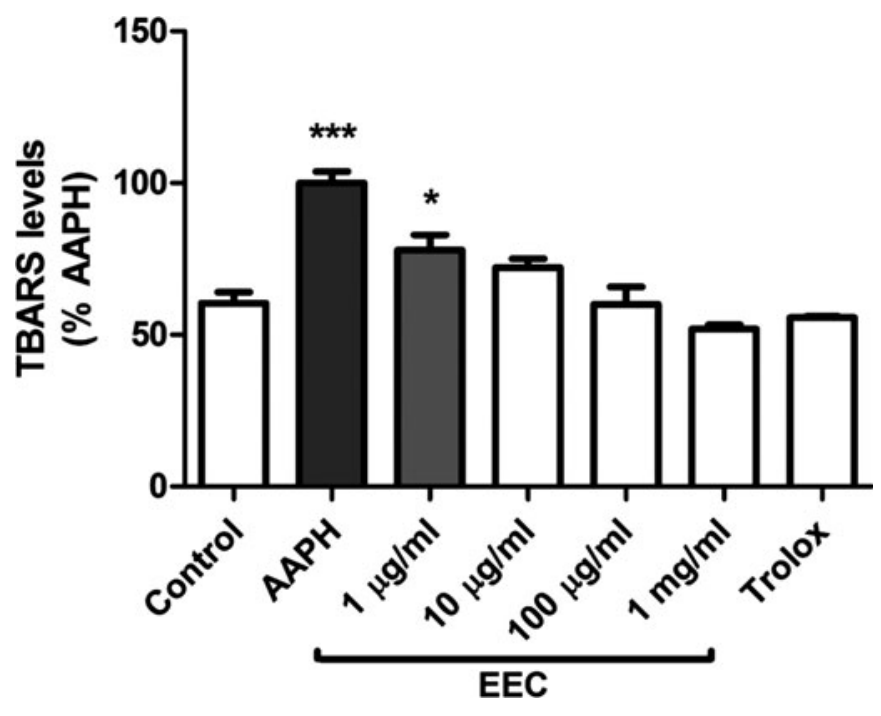

FIG. 1. Thio-barbituric acid-reactive substances (TBARS) in vitro. A lipid-rich system was incubated with a free-radical source $\left(2,2^{\prime}\right.$ azobis(2-amidinopropan) dihydrochloride [AAPH]) and the effect of different concentrations of ethanolic extract of Combretum duarteanum (EEC) on the lipoperoxidation was measured by quantifying TBARS. "Control" refers to incubation medium without AAPH; other groups contained AAPH alone or in the presence of different concentrations of EEC. Trolox ${ }^{\circledR}$ was used as standard antioxidant. Bars represent mean \pm standard error of the mean. $* P<.05$, $* * * P<.0001$ (1-way analysis of variance followed by Tukey multiple comparison post hoc test). AAPH, 2,2'-azobis(2-amidinopropan) dihydrochloride; EEC, ethanolic extract of Combretum duarteanum; TBARS, thio-barbituric acid-reactive substances.

lipid-rich system, such as in the TBARS assay, lipids with lesser affinity to EEC or hydrophilic portions of amphipathic lipids are more susceptible to radical attack, allowing the initiation of lipoperoxidation chain reaction. ${ }^{16}$

We next investigated the antioxidant potential of EEC against 2 different reactive species in vitro. EEC exerted a significant scavenging effect against $\mathrm{NO}$, but higher concentrations reversed this NO-inhibiting effect and led to a small increase in NO production compared with lower concentrations (Fig. 2).

On the other hand, EEC had a strong scavenging effect against hydroxyl radicals generated in vitro in a dosedependent fashion (Fig. 3). These results suggest that the protection against lipoperoxidation chain reactions observed in TBARS assay is probably due to interaction of EEC components with hydroxyl radicals, which is a reactive oxygen species, instead with NO, which is a reactive nitrogen species. Although EEC demonstrated an NOscavenging effect at certain concentrations, some of its components probably enhance NO production or cancel the effect of NO scavengers in EEC when present at higher concentrations. Shifts from antioxidant to pro-oxidant effects against specific radicals are common in analyses of complex mixtures such as plant extracts because many components present different redox properties depending on their concentrations. ${ }^{16,19,28}$

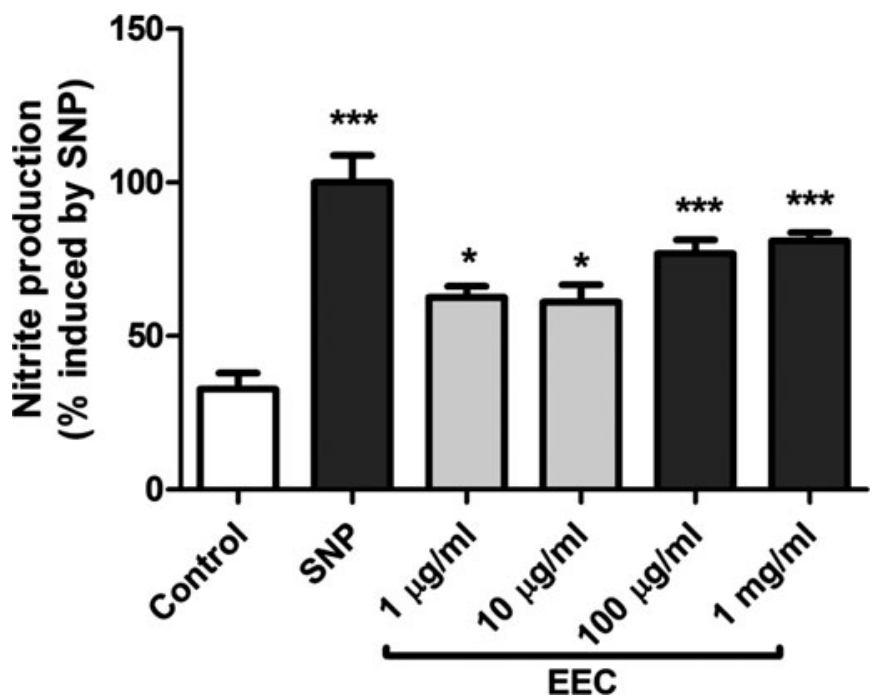

FIG. 2. Nitric oxide-scavenging assay. Nitric oxide is generated from spontaneous decomposition of sodium nitroprusside and interacts with oxygen to produce nitrite ions, which are measured by the Griess reaction. Groups consisted of sodium nitroprusside alone and nitrite production by sodium nitroprusside in the presence of different concentrations of ethanolic extract of Combretum duarteanum. Bars represent mean \pm standard error of the mean. $* * * P<.0001 ; * P<.05$. One-way analysis of variance followed by Tukey multiple comparison post hoc test was applied to all data. EEC, ethanolic extract of Combretum duarteanum; SNP, sodium nitroprusside.

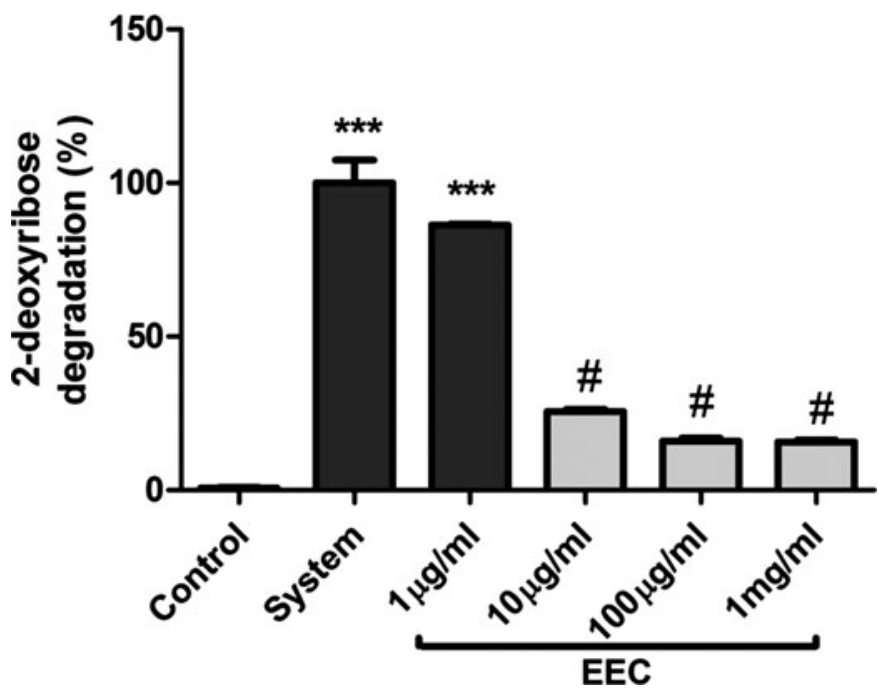

FIG. 3. Hydroxyl radical-scavenging activity was quantified by using 2-deoxyribose oxidative degradation in vitro, which produces malondialdehyde by condensation with 2-thiobarbituric acid. "System" is malondialdehyde production from 2-deoxyribose degradation with $\mathrm{FeSO}_{4}$ and $\mathrm{H}_{2} \mathrm{O}_{2}$ alone. Other groups denote malondialdehyde production by $\mathrm{FeSO}_{4}$ and $\mathrm{H}_{2} \mathrm{O}_{2}$ in the presence of different concentrations of EEC. Bars represent mean \pm standard error of the mean. $* * * P<.0001 ; * P<.05$. One-way analysis of variance followed by Tukey multiple comparison posthoc test was applied to all data. EEC, ethanolic extract of Combretum duarteanum. 
In the acetic acid-induced writhing test, the antinociceptive effect represented by writhe reduction, elicited by 100,200 , and $400 \mathrm{mg} / \mathrm{kg}$ of EEC (mean number of writhes \pm standard error of the mean, $1.5 \pm 0.6,4.1 \pm 1.2$, and $3.1 \pm 0.9$, respectively) in mice was similar to that of $5 \mathrm{mg} / \mathrm{kg}$ morphine (1.3 \pm 0.5$)$, a standard opioid drug, when groups were compared with control (12.6 \pm 2.7$)$ (Table 1). Naloxone $(1.5 \mathrm{mg} / \mathrm{kg}$, intraperitoneally) antagonized the antinociceptive response of morphine from $1.3 \pm 0.5$ (with vehicle only) to $10.2 \pm 2.9$ (with vehicle plus naloxone) writhes in the acetic acid-induced writhing test. Similarly, naloxone antagonized the effect of EEC $(400 \mathrm{mg} / \mathrm{kg})$ (9.7 \pm 4.7$)$ when compared with control (Table 1$)$.

Our results show that EEC produced a dose-dependent inhibition of inflammatory pain in mice, as determined by a significant reduction in acetic acid-induced abdominal writhing. Acetic acid-induced abdominal constriction is a standard, simple, and sensitive test for measuring analgesia induced by both opioids and peripherally acting analgesics. $^{22}$ This test, besides being the most appropriate antinociceptive model for opioids, ${ }^{29,30}$ is also commonly used as a model of visceral inflammatory pain. ${ }^{31}$ In acetic acidinduced abdominal writhing, pain is elicited by the injection of an irritant such as acetic acid into the peritoneal cavity, which produces episodes of characteristic stretching (writhing) movements, and inhibition of the number of episodes by analgesics is easily quantifiable. ${ }^{16,32}$ Central analgesic action was suggested by the blocking effect of naloxone, a specific antagonist of morphinomimetic receptors. $^{33}$

EEC significantly inhibited the licking response to the injected paw when $400 \mathrm{mg} / \mathrm{kg}$ (duration of licking, $612.8 \pm 5.9$ seconds) was administered intraperitoneally in mice compared with the control group ( $42.0 \pm 7.2$ seconds) in the first phase of the formalin test (Table 2). However, EEC $(200$ and $400 \mathrm{mg} / \mathrm{kg})$ significantly $(P<.001)$ inhibited the second phase. As expected, morphine $(5 \mathrm{mg} / \mathrm{kg})$ also reduced the licking time in both phases of this test $(2.1 \pm 0.9$ seconds; $4.8 \pm 2.1$ seconds), whereas aspirin $(200 \mathrm{mg} / \mathrm{kg})$

\section{Table 1. Effect of Ethanolic Extract of Combretum DUARTEANUM, MORPHINE, AND NALOXONE on Writhing Induced by ACETIC ACID}

\begin{tabular}{|c|c|c|c|}
\hline Treatment & Dose $(\mathrm{mg} / \mathrm{kg})$ & Writhings $(n)^{\mathrm{a}}$ & Inhibition (\%) \\
\hline Vehicle & - & $12.6 \pm 2.7$ & - \\
\hline EEC & 100 & $1.5 \pm 0.6^{b}$ & $88.1^{\mathrm{c}}$ \\
\hline EEC & 200 & $4.1 \pm 1.2^{\mathrm{b}}$ & $68.3^{\mathrm{c}}$ \\
\hline EEC & 400 & $3.1 \pm 0.9^{\mathrm{b}}$ & $75.4^{\mathrm{c}}$ \\
\hline $\mathrm{EEC}+$ naloxone & $400+1.5$ & $9.7 \pm 4.7$ & 23.0 \\
\hline Morphine & 5 & $1.3 \pm 0.5^{\mathrm{b}}$ & $89.7^{\mathrm{c}}$ \\
\hline Morphine + naloxone & $5+1.5$ & $10.2 \pm 2.9$ & 19.1 \\
\hline \\
\hline \multicolumn{4}{|c|}{$\begin{array}{l}n=10 . \\
{ }^{a} \text { Values are presented as mean } \pm \text { standard error of the mean. }\end{array}$} \\
\hline \multicolumn{4}{|c|}{${ }^{\mathrm{b}} P<.001$ (1-way analysis of variance and Dunnett test) compared with } \\
\hline
\end{tabular}

Table 2. Effect of Ethanolic Extract of Combretum DUARTEANUM, MORPHINE, AND ASPIRIN ON Formalin-INDUCED PAIN

\begin{tabular}{|c|c|c|c|c|c|}
\hline \multirow[b]{3}{*}{ Treatment } & \multirow[b]{3}{*}{$\begin{array}{c}\text { Dose } \\
(\mathrm{mg} / \mathrm{kg})\end{array}$} & \multicolumn{4}{|c|}{ Licking } \\
\hline & & \multicolumn{2}{|c|}{$0-5 \min$} & \multicolumn{2}{|c|}{$15-30 \mathrm{~min}$} \\
\hline & & $\begin{array}{c}\text { Score of } \\
\text { pain }^{\mathrm{a}}\end{array}$ & $\begin{array}{c}\text { Inhibition } \\
(\%)\end{array}$ & $\begin{array}{c}\text { Score of } \\
\text { pain }^{\mathrm{a}}\end{array}$ & $\begin{array}{c}\text { Inhibition } \\
(\%)\end{array}$ \\
\hline Vehicle & - & $42.0 \pm 7.2$ & - & $54.0 \pm 11.2$ & - \\
\hline EEC & 100 & $45.0 \pm 6.6$ & -7.1 & $33.4 \pm 9.1$ & $38.1^{\mathrm{b}}$ \\
\hline EEC & 200 & $29.2 \pm 9.8$ & $30.5^{\mathrm{b}}$ & $5.1 \pm 4.4^{\mathrm{c}}$ & $90.6^{\mathrm{d}}$ \\
\hline EEC & 400 & $12.8 \pm 5.9^{\mathrm{e}}$ & $69.5^{\mathrm{d}}$ & $1.2 \pm 0.4^{\mathrm{c}}$ & $97.8^{d}$ \\
\hline Morphine & 5 & $2.1 \pm 0.9^{c}$ & $95.0^{\mathrm{d}}$ & $4.8 \pm 2.1^{\mathrm{c}}$ & $91.1^{\mathrm{d}}$ \\
\hline Aspirin & 200 & $35.4 \pm 9.8$ & 15.7 & $3.9 \pm 1.6^{\mathrm{c}}$ & $92.8^{\mathrm{d}}$ \\
\hline \multicolumn{6}{|c|}{$\begin{array}{l}n=10 \text {. } \\
{ }^{\mathrm{a}} \text { Values are presented as mean } \pm \text { standard error of the mean. } \\
{ }^{\mathrm{b}} P<.05 \text { (Fisher test) compared with control. } \\
{ }^{\mathrm{c}} P<.001 \text { (1-way analysis of variance and Dunnett test) compared with } \\
\text { control. } \\
{ }^{\mathrm{d} P} P<.001 \text { (Fisher test) compared with control. } \\
{ }^{\mathrm{e}} P<.05 \text { (1-way analysis of variance and Dunnett test) compared with } \\
\text { control. }\end{array}$} \\
\hline
\end{tabular}

reduced it only during the second phase ( $3.9 \pm 1.6$ seconds). EEC $(100 \mathrm{mg} / \mathrm{kg})$ did not produce any significant changes in either phase of the formalin test.

The advantage of using the formalin model of nociception is that it can discriminate pain in its central and peripheral components. ${ }^{34,35}$ The test consists of 2 different phases separated in time: The first one is generated in the periphery through the activation of nociceptive neurons by the direct action of formalin, and the second occurs through the activation of the ventral horn neurons at the spinal cord level. Morphine, a typical narcotic drug, inhibits nociception in both phases, ${ }^{36}$ but drugs with peripheral action, such as indomethacin and corticosteroids, inhibit only the second phase. Moreover, drugs such as acetylsalicylic acid and paracetamol, which inhibit prostaglandin synthesis, block only the second phase of the formalin test. ${ }^{22,37}$

The analgesic action presented by EEC involves supraspinal as well as spinal components, as demonstrated by the use of the hot-plate test. ${ }^{38}$ The results suggest that EEC $(100,200$, and $400 \mathrm{mg} / \mathrm{kg}$, intraperitoneally) has a central analgesic effect (Table 3), as evidenced by the prolonged delay in response time when mice were subjected to a nociceptive stimulus during a hot-plate test. This central analgesic action was confirmed by the blocking effect of naloxone. $^{33}$

In the Rota-rod test, EEC-treated mice showed no significant motor performance alterations with doses of 100,200 , or $400 \mathrm{mg} / \mathrm{kg}$ (data not shown). As might be expected, the central nervous system depressant diazepam ( $3 \mathrm{mg} / \mathrm{kg}$, intraperitoneally), the standard drug, reduced the time of treated animals on the Rota-rod after 60 minutes (41.5 \pm 10.5 seconds) compared with the control group.

The mean increase in paw edema volume was about $0.89 \pm 0.15 \mathrm{~mL}$ in the vehicle-treated control rats. EEC 
Table 3. Effect of Ethanolic Extract of Combretum duarteanum or Morphine on the Hot-Plate Test in the Absence and Presence of Naloxone in Mice

\begin{tabular}{lccccc}
\hline & & \multicolumn{4}{c}{ Reaction time (licking of hind paws) $(\mathrm{s})^{\mathrm{a}}$} \\
\cline { 3 - 6 } Treatment & $\begin{array}{c}\text { Dose } \\
(\mathrm{mg} / \mathrm{kg})\end{array}$ & Basal & $0.5 \mathrm{~h}$ & $1 \mathrm{~h}$ & $1.5 \mathrm{~h}$ \\
\hline Vehicle & - & $7.5 \pm 2.1$ & $9.8 \pm 1.8$ & $8.9 \pm 1.1$ & $7.7 \pm 1.6$ \\
EEC & 100 & $6.8 \pm 3.7$ & $11.7 \pm 1.6$ & $15.3 \pm 1.4^{\mathrm{b}}$ & $15.9 \pm 1.4^{\mathrm{b}}$ \\
$\mathrm{EEC}$ & 200 & $9.1 \pm 1.9$ & $12.9 \pm 1.3$ & $17.6 \pm 1.3^{\mathrm{b}}$ & $14.5 \pm 1.8^{\mathrm{b}}$ \\
$\mathrm{EEC}$ & 400 & $8.5 \pm 2.7$ & $13.4 \pm 1.3$ & $16.2 \pm 2.7^{\mathrm{b}}$ & $18.4 \pm 2.0^{\mathrm{c}}$ \\
EEC + & $400+1.5$ & $9.2 \pm 2.5$ & $11.0 \pm 2.7$ & $12.5 \pm 2.8$ & $10.2 \pm 2.1$ \\
$\quad$ naloxone & & & & & \\
$\begin{array}{l}\text { Morphine } \\
\text { Morphine }+\end{array}$ & 5 & $8.2 \pm 3.3$ & $25.5 \pm 3.6^{\mathrm{c}}$ & $27.3 \pm 4.5^{\mathrm{d}}$ & $29.3 \pm 1.9^{\mathrm{d}}$ \\
$\quad$ naloxone & $5+1.5$ & $7.8 \pm 3.4$ & $9.4 \pm 2.1$ & $13.4 \pm 3.3$ & $8.8 \pm 3.9$ \\
\hline
\end{tabular}

$n=10$.

${ }^{\mathrm{a}}$ Values are presented as mean \pm standard error of the mean.

${ }^{\mathrm{b}} P<.05$ (Fisher test) compared with control.

${ }^{\mathrm{c}} P<.001$ (1-way analysis of variance and Dunnett test) compared with control.

${ }^{\mathrm{d}} P<.001$ (Fisher test) compared with control.

(200 and $400 \mathrm{mg} / \mathrm{kg}$, intraperitoneally) significantly $(P<$ .05 ) reduced the mean paw edema volume at 3 hours after carrageenan injection. EEC (200 and $400 \mathrm{mg} / \mathrm{kg}$, intraperitoneally) exhibited anti-inflammatory activity with $53.9 \%$ and 56.25 inhibition of paw edema, respectively, as compared with the control group. However, the standard drug, aspirin $(200 \mathrm{mg} / \mathrm{kg}$, intraperitoneally), showed highly significant $(P<.01)$ anti-inflammatory activity $(76.4 \%$ inhibition) (Table 4).

Various mediators are released by carrageenan in the rat paw. Thus, although the initial phase may be due to the release of histamine and serotonin, kinins may play a role in

Table 4. Effect of Ethanolic Extract of Combretum DUARTEANUM OR ASPIRIN ON CARRAGEENAN-INDUCED Hind-PAw EDEMa in Rats

\begin{tabular}{lccc}
\hline Treatment & $\begin{array}{c}\text { Dose } \\
(\mathrm{mg} / \mathrm{kg})\end{array}$ & $\begin{array}{c}\text { Carrageenan-induced } \\
\text { hind-paw edema } \\
\text { volume }(\mathrm{mL})^{\mathrm{a}}\end{array}$ & $\begin{array}{c}\text { Inhibition } \\
(\%)\end{array}$ \\
\hline Vehicle & - & $0.89 \pm 0.15$ & - \\
EEC & 100 & $0.73 \pm 0.17$ & 18.0 \\
EEC & 200 & $0.41 \pm 0.12^{\mathrm{b}}$ & $53.9^{\mathrm{c}}$ \\
EEC & 400 & $0.39 \pm 0.09^{\mathrm{b}}$ & $56.2^{\mathrm{c}}$ \\
Aspirin & 200 & $0.21 \pm 0.05^{\mathrm{d}}$ & $76.4^{\mathrm{c}}$ \\
\hline
\end{tabular}

$n=8$.

${ }^{\mathrm{a}}$ Values are presented as mean \pm standard error of the mean.

${ }^{\mathrm{b}} P<=.05$ (1-way analysis of variance and Dunnett test) compared with control.

${ }^{\mathrm{c}} P<.001$ (Fisher test) compared with control.

${ }^{\mathrm{d}} P<.01$ (1-way analysis of variance and Dunnett test) compared with control. the middle phase, ${ }^{39}$ and prostaglandins could be the most important mediators in the final 3- to 5-hour postcarrageenan response. ${ }^{26,40}$ Table 4 shows that EEC more strongly inhibited paw edema, suggesting that the extract may have a selective inhibitory effect on the release or actions of prostaglandin mediators. In addition, the antioxidant action of EEC observed in the TBARS and NO assays suggests that this extract may protect against oxidative damage to membrane polyunsaturated fatty acids, such as arachidonic acid, which is a very important component in the response to pain via the cyclooxygenase pathway. ${ }^{41}$

Moreover, the paw edema induced by arachidonic acid is a widely used method for distinguishing between 5-lipooxygenase and cyclooxygenase inhibitors. ${ }^{42}$ Subplantar injection of arachidonic acid produced significant edema as early as 30 minutes afterward and reached a peak at 90 minutes (200 and $400 \mathrm{mg} / \mathrm{kg}$ ).

EEC (200 and $400 \mathrm{mg} / \mathrm{kg}$ ) reduced edema formation when administered intraperitoneally, similar to NDGA (reference drug) (Table 5). The rat paw edema induced by arachidonic acid is perceptibly reduced by inhibitors of arachidonic acid metabolism and by corticosteroids and is insensitive to selective cyclooxygenase inhibitors. ${ }^{43}$ On the basis of the present results, we may propose that EEC has an anti-inflammatory action interfering with prostaglandin synthesis.

\section{CONCLUSION}

Our results suggest that the ethanolic extract of $C$. duarteanum (EEC) exhibits an antioxidant action that prevents lipoperoxidation, probably due to hydroxyl radicalscavenging activity, and a clear antinociceptive activity in mice. Its antinociceptive effect probably occurs via central

Table 5. Effect of Ethanolic Extract of Combretum duarteanum on Arachidonic Acid-Induced Rat Paw Edema

\begin{tabular}{|c|c|c|c|c|}
\hline \multirow[b]{2}{*}{$\begin{array}{l}\text { Time } \\
\text { (min) }\end{array}$} & \multicolumn{4}{|c|}{$\begin{array}{l}\text { Arachidonic acid-induced hind-paw } \\
\text { edema volume }(m L)^{\mathrm{a}}\end{array}$} \\
\hline & Control & $N D G A$ & $\begin{array}{c}E E C, \\
200 \mathrm{mg} / \mathrm{kg}\end{array}$ & $\begin{array}{c}E E C \\
400 \mathrm{mg} / \mathrm{kg}\end{array}$ \\
\hline $\begin{array}{l}30 \\
60 \\
90 \\
120 \\
\text { Inhibition }^{\mathrm{d}}\end{array}$ & $\begin{array}{l}0.31 \pm 0.04 \\
0.51 \pm 0.05 \\
0.53 \pm 0.04 \\
0.56 \pm 0.06 \\
\quad-\end{array}$ & $\begin{array}{l}0.08 \pm 0.03^{\mathrm{b}} \\
0.12 \pm 0.05^{\mathrm{b}} \\
0.18 \pm 0.10^{\mathrm{b}} \\
0.23 \pm 0.12^{\mathrm{b}} \\
\quad 68.1^{\mathrm{e}}\end{array}$ & $\begin{array}{l}0.26 \pm 0.09^{\mathrm{b}} \\
0.29 \pm 0.11^{\mathrm{c}} \\
0.32 \pm 0.07^{\mathrm{c}} \\
0.45 \pm 0.16 \\
\quad 30.9^{\mathrm{f}}\end{array}$ & $\begin{array}{l}0.17 \pm 0.06^{\mathrm{b}} \\
0.23 \pm 0.13^{\mathrm{b}} \\
0.22 \pm 0.09^{\mathrm{b}} \\
0.36 \pm 0.09^{\mathrm{c}} \\
\quad 48.7^{\mathrm{e}}\end{array}$ \\
\hline \multicolumn{5}{|c|}{$\begin{array}{l}n=8 \text {. } \\
{ }^{\mathrm{a}} \text { Values with plus/minus sign are presented as mean } \pm \text { standard error of the } \\
\text { nean. } \\
{ }^{\mathrm{b}} P<.01 \text { (1-way analysis of variance and Dunnett test) compared with } \\
\text { control. } \\
{ }^{\mathrm{c}} P<.05 \text { (1-way analysis of variance and Dunnett test) compared with control. }\end{array}$} \\
\hline
\end{tabular}


inhibitory mechanisms (opioid system) and is not due to changes in motor coordination. The probable antiinflammatory activity of the extract may play a role in actions that interfere with prostaglandin synthesis and also might involve redox-mediated mechanisms. Further studies currently in progress will enable us to understand the precise mechanisms of action.

\section{ACKNOWLEDGMENTS}

We thank Mr. Osvaldo Andrade Santos for the technical support. This work was supported by grants from Conselho Nacional de Desenvolvimento Científico e Tecnológico (Edital MCT/CNPq 14/2008 Universal, Processo number 470290/2008) and Fundação de Apoio à Pesquisa do Estado da Paraíba (Edital 001/2008 FAPESQ-PB/MCT/CNPq, termo 191/08).

\section{AUTHOR DISCLOSURE STATEMENT}

No competing financial interests exist. All the authors have substantially participated in the investigation, data analysis, and the preparation of the manuscript and accept full responsibility for its content.

\section{REFERENCES}

1. Quintans-Júnior LJ, Souza TT, Leite BS, et al.: Phythochemical screening and anticonvulsant activity of Cymbopogon winterianus Jowitt (Poaceae) leaf essential oil in rodents. Phytomedicine 2008;15:619-624.

2. De Souza MM, Pereira MA, Ardenghi JV, et al:: Filicene obtained from Adiantum cuneatum interacts with the cholinergic, dopaminergic, glutamatergic, GABAergic, and tachykinergic systems to exert antinociceptive effect in mice. Pharmacol Biochem Behav 2009;93:40-46.

3. Menezes IAC, Moreira IJA, Paula JWA, et al.: Cardiovascular effects induced by Cymbopogon winterianus essential oil in rats: involvement of calcium channels and vagal pathway. J Pharm Pharmacol 2010;62:215-221.

4. Calixto JB, Beirith A, Ferreira J, et al.: Naturally occurring antinociceptive substances from plants. Phytother Res 2000;14: 401-418.

5. Barbosa-Filho JM, Medeiros KCP, Diniz MFFM, et al.: Natural products inhibitors of the enzyme acetylcholinesterase. Rev Bras Farmacogn 2006;16:258-285.

6. Melo MS, Sena LCS, Barreto FJN, et al.: Antinociceptive effect of citronellal in Mice. Pharm Biol 2010;48:411-416.

7. Pietrovski EF, Rosa KA, Facundo VA, et al.: Antinociceptive properties of the ethanolic extract and of the triterpene $3 \beta, 6 \beta, 16 \beta$-trihidroxilup-20(29)-ene obtained from the flowers of Combretum leprosum in mice. Pharmacol Biochem Behav 2006;83:90-99.

8. Albuquerque UP, Medeiros PM, Almeida ALS, et al.: Medicinal plants of the caatinga (semi-arid) vegetation of $\mathrm{NE}$ Brazil: a quantitative approach. J Ethnopharmacol 2007;114: 325-354.

9. McGaw LJ, Rabe T, Sparg SG, et al.: An investigation on the biological activity of Combretum species. J Ethnopharmacol 2001;75:45-50.
10. Lira SRD, Almeida RN, Almeida FRC, Oliveira FS, Duarte JC: Preliminary studies on the analgesic properties of the ethanol extract of Combretum leprosum. Pharm Biol 2002;40:213-215.

11. Young SL, Chaplin DJ: Combrestatin A-4 phosphate: background and current clinical status. Exp Opin Invest Drugs 2004;13:1171-1182.

12. Martini ND, Katerere DRP, Eloff JN: Biological activity of antibacterial flavonoids from Combretum erythrophyllum (Combretaceae). J Ethnopharmacol 2004;93:207-212.

13. Nascimento SC, Chiappeta AA, Lima RMOC: Antimicrobial and cytotoxic activities in plants from Pernambuco, Brazil. Fitoterapia 1990;61:353-355.

14. Agra MF, Baracho GS, Nurit B, Basílio IJLD, Coelho VPM: Medicinal and poisonous diversity of the flora of "Cariri Paraibano”, Brazil. J Ethnopharmacol 2007;111:383-395.

15. Halliwell B, Gutteridge JMC: Free Radicals in Biology and Medicine. 4th ed. Oxford, Oxford University Press, 2007.

16. Guimarães AG, Oliveira GF, Melo MS, et al.: Bioassay-guided evaluation of antioxidant and antinociceptive activities of carvacrol. Basic Clin Pharmacol Toxicol 2010;107:949-957.

17. Esterbauer H, Cheeseman KH: Determination of aldehydic lipid peroxidation products: malonaldehyde and 4-hydroxynonenal. Methods Enzymol 1990;186:407-421.

18. Lopes GK, Schulman HM, Hermes-Lima M: Polyphenol tannic acid inhibits hydroxyl radical formation from Fenton reaction by complexing ferrous ions. Biochim Biophys Acta 1999;1472:142152.

19. Basu S, Hazra B: Evaluation of nitric oxide scavenging activity, in vitro and ex vivo, of selected medicinal plants traditionally used in inflammatory diseases. Phytother Res 2006;20:896-900.

20. Koster R, Anderson M, Beer EJ: Acetic acid for analgesic screening. Fed Proceed 1959;18:412-416.

21. Broadbear JH, Negus SS, Butelman ER, Costa BR, Woods JH: Differential effects of systemically administered nor-binaltorphimine (nor-BNI) on $\kappa$-opioid agonists in mouse writhing assay. Psychopharmacology 1994;15:311-319.

22. Hunskaar S, Hole K: The formalin test in mice: dissociation between inflammatory and non-inflammatory pain. Pain 1987;30: 103-104.

23. Eddy NB, Leimbach D: Synthetic analgesics. II. Dithienylbutenyland dithienylbutylamines. J Pharmacol Exp Ther 1953;107:385393.

24. Oliveira FA, Almeida RN, Sousa MF, et al.: Anticonvulsant properties of $\mathrm{N}$-salicyloyltryptamine in mice. Pharmacol Biochem Behav 2001;68:199-202.

25. Winter CA, Riseley EA, Nuss GW: Carrageenan-induced edema in the hind paw of the rats as an assay for anti-inflammatory drugs. Proc Soc Exp Biol Med 1962;111:544-547.

26. Arrigoni-Blank MF, Dmitrieva EG, Franzotti EM, et al.: Antiinflammatory and analgesic activity of Peperomia pellucida (L.) HBK (Piperaceae). J Ethnopharmacol 2004;91:215-218.

27. Reanmongkol W, Matsumoto K, Watanabe H, Subhadhirasakul S, Sakai SI: Antinociceptive and antipyretic effects of alkaloids extracted from the stem bark of Hunteria zeylanica. Biol Pharm Bull 1994;17:1345-1350.

28. Halliwell B: Are polyphenols antioxidants or pro-oxidants? What do we learn from cell culture and in vivo studies? Arch Biochem Biophys 2008;476:107-112.

29. Hayes AG, Sheehan MJ, Tyers TB: Differential sensitivity of models of antinociception in the rat, mouse and guinea-pig to 
mu- and kappa-opioid receptor agonists. Br J Pharmacol 1987; 91:823-832.

30. Shaw JS, Rourke JD, Burns KM: Differential sensitivity of antinociceptive tests to opioid agonists and partial agonists. $\mathrm{Br} \mathrm{J}$ Pharmacol 1988;95:578-584.

31. Barber A, Gottschlich R: Opioid agonists and antagonists: an evaluation of their peripheral actions in inflammation. Med Res Rev 1992;12:525-562.

32. Melo MGD, Araujo AAS, Rocha CPL, et al.: Purification, physicochemical properties, thermal analysis and antinociceptive effect of atranorin extracted from Cladina kalbii. Biol Pharm Bull 2008;31:1977-1980.

33. Belvisi MG, Chung DM, Barnes PJ: Opioid modulation of noncholinergic neural bronchoconstriction in guinea-pig in vivo. $\mathrm{Br} \mathrm{J}$ Pharmacol 1998;95:413-418.

34. Tjolsen A, Berge OG, Hunskaar S, Rosland JH, Hole K: The formalin test: an evaluation of the method. Pain 1992;51:5-17.

35. Quintans-Júnior LJ, Melo MS, De Sousa DP, et al.: Antinociceptive activity of citronellal in formalin-, capsaicin- and glutamate-induced orofacial nociceptionpain in rodents and its action on nerve excitability. J Orofac Pain 2010;24:305-312.
36. Shibata M, Ohkubo T, Takahashi H, Inoki R: Modified formalin test: characteristic biphasic pain response. Pain 1989;38:347352.

37. Rosland JH, Tjolsen A, Maehle B, Hole K: The formalin test in mice effect of formalin concentration. Pain 1990;42:235-242.

38. Yaksh TL, Rubi TA: Analgesia mediated by a direct spinal action of narcotics. Science 1976;192:1357-1358.

39. Di Rosa M, Sorrentino L: The mechanism of the inflammatory effect of carrageenan. Eur J Pharmacol 1968;4:340-342.

40. Vinegar R, Schreiber W, Hugo R: Biphasic development of carrageenan edema in rats. J Pharmacol Exp Ther 1969;166;96-103.

41. Salvemini D, Doyle TM, Cuzzocrea S: Superoxide, peroxynitrite and oxidative/nitrative stress in inflammation. Biochem Soc Trans 2006;34:965-970.

42. Griswold DE, Marshall PJ, Webb EF, et al.: SK\&F 86002: a structurally novel anti-inflammatory agent that inhibits lipoxygenase and cyclooxygenase mediated metabolism of arachidonic acid. Biochem Pharmacol 1987;36:3463-3470.

43. DiMartino MJ, Campbell Jr GK, Wolf CE, Hanna N: The pharmacology of arachidonic acid-induced rat paw edema. Agents Actions 1987;21:303-305. 